\title{
PENGARUH MINUM JUS ANGGUR DAN JUS JAMBU BIJI DENGAN DAN TANPA GULA TERHADAP PERUBAHAN PH SALIVA
}

\author{
Ratnawati Hendari*, Irma HY Siregar*
}

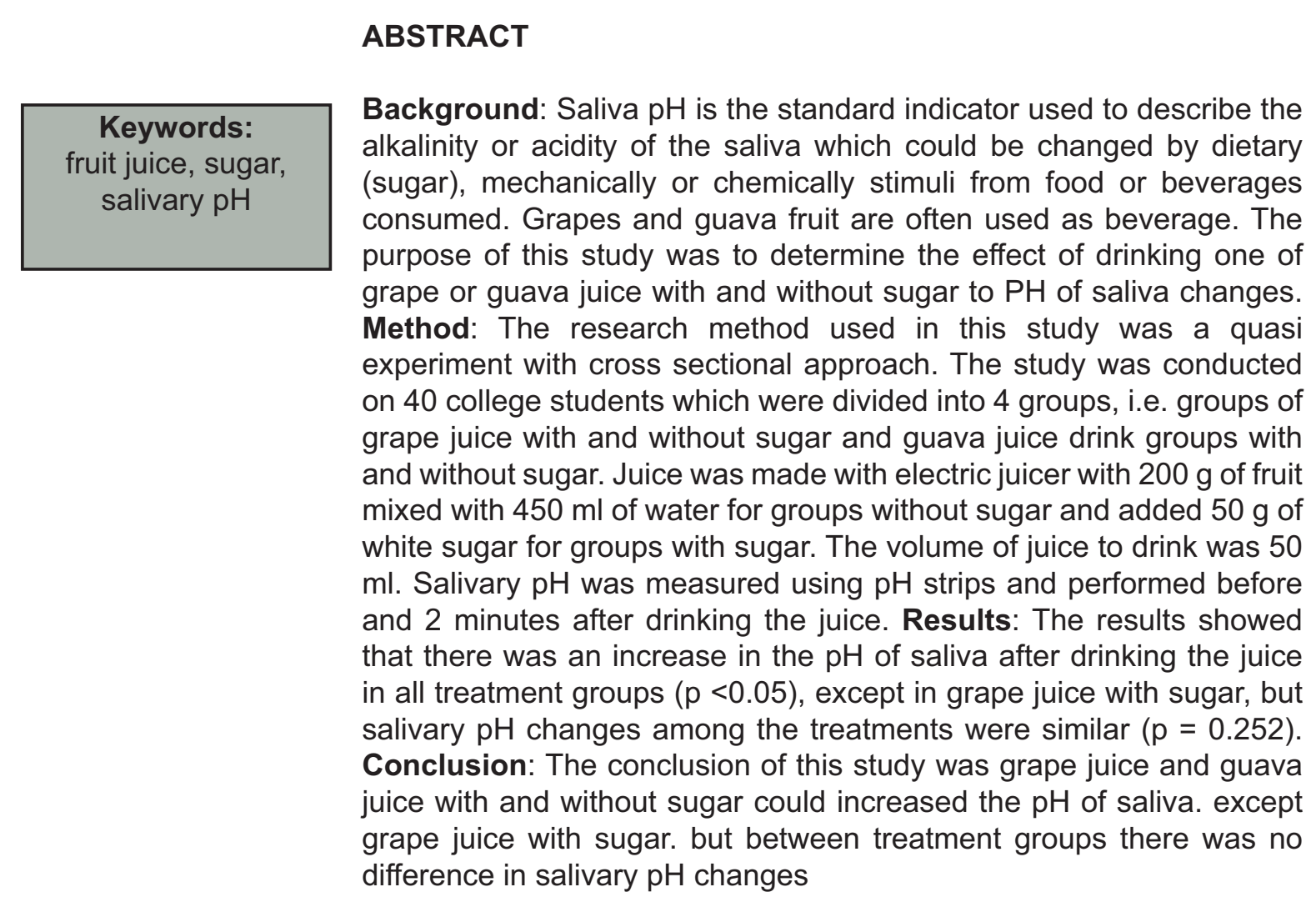

\section{PENDAHULUAN}

Karies gigi merupakan penyakit gigi dan mulut yang paling banyak terjadi di Indonesia. Karies dapat terjadi pada siapa saja, walaupun umumnya sering muncul pada usia anak atau dewasa muda. Karies inilah yang merupakan penyebab utama kehilangan gigi pada usia muda. Menurut data Riskesdas 2007 masalah karies memliki kecenderungan meningkat sejalan dengan bertambahnya umur. Prevalensi karies anak usia 8 tahun sebesar $45,2 \%$, usia 12 tahun sebesar $76,62 \%$. Prevalensi karies meningkat sampai umur 35-44 tahun dan menurun kembali pada umur 65 tahun ${ }^{1}$.

Karies adalah proses demineralisasi email gigi yang disebabkan oleh interaksi antara mikroorganisme, saliva, bagian- bagian yang berasal dari makanan dan email yang diikuti oleh kerusakan bahanbahan hasil fermentasi karbohidrat yang dilakukan oleh bakteri patogen dalam rongga mulut berupa asam laktat. Asam laktat akan menurunkan keasaman $(\mathrm{pH})$ saliva organiknya. Proses demineralisasi disebabkan oleh paparan asam organik sampai di bawah 5 dalam tempo 1-3 menit. Jika $\mathrm{pH}$ turun berulang-ulang dalam waktu tertentu mengakibatkan terjadinya demineralisasi pada permukaan gigi yang rentan sehingga proses karies dimulai. Burt dan Pai mengatakan bahwa ada hubungan antara mengkonsumsi karbohidrat dengan karies ${ }^{2}$. Secara pengamatan klinis, ada hubungan antara diet karbohidrat dalam minuman dengan karies. Resiko terjadi karies yang tinggi

*Staf Pengajar Jurusan Keperawatan Gigi Politeknik Kesehatan Kemenkes Semarang

Korespondensi: ratnaagung@yahoo.com 
jika sering mengkonsumsi makanan minuman manis di antara jam makan ${ }^{3}$.

Penelitian- penelitian yang sudah dipublikasikan di jurnal of American Dental Association menjelaskan adanya hubungan yang bermakna masalah karies yang disebabkan oleh berbagai jenis minuman ${ }^{4}$, kebiasaan minum minuman yang sedang popular ${ }^{5,6}$.

Untuk saat ini, masyarakat Indonesia suka minum jus, termasuk jus anggur dan jambu biji. Anggur dan jambu biji memiliki warna merah, memiliki biji, rasa manis. Jambu biji mengandung 183mg vitamin C, $11.88 \mathrm{~g}$ karbohidrat. Sementara anggur mengandung $108 \mathrm{mg}$ vitamin C, $18.1 \mathrm{~g}$ karbohidrat, serat (USDA Nutrient Database untuk Standard Reference, isi buah per 100gram).

Saliva mempunyai peranan penting dalam proses terjadinya karies gigi karena salah satu fungsi saliva adalah sebagal bufer dan netralisasi $\mathrm{pH}$

Tabel 1. Rerata pH saliva sebelum dan sesudah minum jus atau menjaga $\mathrm{pH}$ optimal. Perubahan $\mathrm{pH}$ saliva dipengaruhi oleh kecepatan sekresi saliva, viskositas saliva, kuantitas saliva.

Tujuan penelitian ini adalah untuk mengetahui pengaruh minum jus anggur dan jus jambu biji dengan dan tanpa gula terhadap perubahan $\mathrm{pH}$ saliva.

\section{METODE PENELITIAN}

Metode penelitian yang di gunakan dalam penelitian ini adalah Quasi Experiment pre-post test group design dengan pendekatan cross sectional. Penelitian dilakukan pada mahasiswa sebanyak 40 orang yang dibagi dalam 4 kelompok, yaitu kelompok minum jus anggur dengan dan tanpa gula serta kelompok minum jus jambu biji dengan dan tanpa gula. Jus dibuat dengan juicer dengan $200 \mathrm{~g}$ buah dicampur dengan $450 \mathrm{ml}$ air dan ditambahkan 50 anggur dan jus jambu biji dengan atau tanpa gula

g gula putih. Volume jus untuk minuman adalah $50 \mathrm{ml}$ tanpa sedotan kemudian menenggak tanpa kumur. Saliva pH diukur menggunakan strip $\mathrm{pH}$ dan dilakukan sebelum dan 2 menit setelah minum jus. Analisis data menggunakan paired t-test dan ANOVA.

\section{HASIL PENELITIAN}

Perubahan $\mathrm{pH}$ saliva telah dibandingkan antar kelompok perlakuan dengan mengukur $\mathrm{pH}$ saliva sebelum dan sesudah perlakuan. Data hasil pengukuran ditampilkan pada tabel di bawah ini (Tabel 1).

\begin{tabular}{ccccc}
\hline Jenis jus & & Sebelum & Sesudah & Selisih \\
\hline Anggur & Dengan gula & 6.84 & 7.06 & 0.22 \\
& Tanpa gula & 6.82 & 7.14 & 0.32 \\
Jambu Biji & Dengan gula & 6.84 & 7.26 & 0.42 \\
& Tanpa gula & 6.74 & 7.22 & 0.48 \\
\hline
\end{tabular}
$\mathrm{pH}$ saliva setelah minum jus pada semua kelompok perlakuan. Hasil uji Paired T-test diperoleh perbedaan yang bermakna antara $\mathrm{pH}$ saliva sebelum dan sesudah minum jus pada semua kelompok perlakuan kecuali kelompok minum jus anggur dengan gula. Hasi uji ANOVA menunjukkan tidak adanya perbedaan perubahan $\mathrm{pH}$ saliva antar kelompok perlakuan $(p=0.252)$.

\section{DISKUSI}

Adanya perubahan $\mathrm{pH}$ saliva menjadi lebih tinggi setelah minum jus pada semua kelompok perlakuan. Hal ini disebabkan karena jenis gula dan aktivitas gerakan mekanis (minum menggunakan gelas) dan stimulasi kimiawi dari buah anggur dan buah jambu biji. Gula yang
Tabel 1 menunjukkan adanya kenaikan 
terkandung dalam karbohidrat pada buah-buahan adalah jenis fruktosa (monosakarida). Fruktosa bukanlah media yang baik bagi bakteri untuk melakukan fermentasi karbohidrat, sehingga asam laktat tidak terbentuk. Gerakan mekanis dengan minum menggunakan gelas dan rangsangan kimiawi berupa rasa dari buah akan memacu pengeluaran sekresi saliva sehingga menaikkan $\mathrm{pH}$ saliva. Keadaan $\mathrm{pH}$ saliva dipengaruhi oleh adanya stimulasi. $\mathrm{pH}$ saliva naik cepat setelah distimulasi ringan dan berjalan dari $\mathrm{pH}$ 6,0 sampai 7,4 pada kecepatan sekresi $1 \mathrm{ml} /$ menit, $\mathrm{pH}$ nya berjalan seimbang dengan konsentrasi bikarbonat.

Kenaikan $\mathrm{pH}$ saliva pada kelompok minum jus anggur lebih kecil dibandingkan kelompok minum jambu biji. $\mathrm{Hal}$ ini disebabkan karena kandungan vitamin C dan karbohidrat dalam buah. Pada. buah anggur memiliki kandungan vitamin C sebesar $108 \mathrm{mg} / 100 \mathrm{~g}$ buah anggur sedangkan buah jambu biji memiliki kandungan vitamin C sebesar 183 $\mathrm{mg} / 100 \mathrm{~g}$ buah jambu biji. Vitamin $\mathrm{C}$ yang tinggi juga berpengaruh terhadap $\mathrm{pH}$ saliva. Makanan yang mengandung vitamin $\mathrm{C}$ dalam jumlah tinggi akan menyebabkan saliva lebih encer atau kekentalan saliva menjadi lebih rendah.

Penurunan $\mathrm{pH}$ saliva terjadi setelah minum jus buah yang menggunakan gula. Hal ini karena jenis gula sukrosa (disakarida). Sukrosa adalah media yang tepat bagi bakteri untuk fermentasi karbohidrat. Hal ini sesuai dengan pendapat Pradhan, dkk (2013) bahwa hasil fermentasi karbohidrat yang dilakukan oleh bakteri patogen dalam rongga mulut dalam bentuk asam laktat. Asam laktat akan menurunkan keasaman $(\mathrm{pH})$ dari saliva organik ${ }^{7}$. Jenis gula sukrosa adalah yang paling berbahaya karena merupakan jenis gula yang paling mudah diubah menjadi asam oleh mikroba Streptococcus mutans dalam rongga mulut. Sekitar dua menit setelah gula ke dalam plak gigi, Streptococcus mutans menghasilkan asam yang dapat mengurangi kadar mineral dalam gigi.

\section{KESIMPULAN}

Minum jus anggur dan jus jambu biji dengan dan tanpa gula dapat meningkatkan $\mathrm{pH}$ saliva. kecuali kelompok minum jus anggur dengan gula. tetapi antara kelompok perlakuan tidak ada perbedaan dalam perubahan $\mathrm{pH}$ saliva

\section{DAFTAR PUSTAKA}

1. Depkes RI. Laporan Hasil Riset Kesehatan Dasar (RISKESDAS) Nasional. 2007

2. Burt, B. A., Pai, S. Sugar consumtion and caries risk: A systematic review. J Dent Education. 2001. 65(10):1017-1023

3. Curnow, M M T., Pine, C M., Burnside, G., Nicholson, J. A., A randomised controlled trial of the efficacy of supervised toothbrushing in high caries risk children. Caries research. 2002. 36(4):294-9

4. Sohn, W., Burt, B. A. Sawers, M. R., Carbonated soft drinks and dental caries in the primary dentition. J Dent Res. 2006. 85(3):262-266

5. Mulvany, D. Soft drinks and caries. J Am Dent Assoc. 2001. 132:1083

6. Yaghi, MM. Letters: Soda pop and caries. J Am Dent Assoc. 2001. 132:576-577.

7. Pradhan, D., Suri, KA., Pradhan, DK, Biswasroy, P., Golden Heart of The Nature: Piper betle L. J.of Pharmacognosy and Phytochemistry, 2013, 1(6):147-167 